\title{
Geological Survey in a Modern Society
}

\author{
SIR KINGSLEY DUNHAM \\ Director of the Institute of Geological Sciences, London
}

THE object of a geological survey is to produce maps showing the distribution and relationships of the consolidated rocks of the earth's crust exposed at the land surface or on the sea bottom, and of the drift formations which may cover them. The purpose of this review is to consider the scientific justification for such activity, the methods by which it may be carried on, and its relevance to the practical needs of a modern society. Geological surveys may be made by individuals for pure scientific objects, or by industry in connexion with the search for fuels and minerals, or with the assessment of foundation conditions for civil engineering works ; but in nearly all countries, be they developed or developing, they are also an activity of government. Special emphasis is placed here on this latter aspect.

In Britain, the oldest scientific institution wholly supported by the state is the Royal Greenwich Observatory, founded 1675, through which passes, by international agreement, the zero meridian of longitude. The second oldest is the Geological Survey of Great Britain, founded in 1835. Though now merged with the Institute of Geological Sciences, it continues its work and I write as thirteenth director in line from Sir Henry De la Beche FRS, its founder. The remarks of one of its most influential sponsors at the time of foundation, Sir Charles Lyell, are wotrh quoting:

" not only as calculated to promote geological science, which would alone be a sufficient object, but also as a work of great practical utility, bearing on agriculture, mining, road making, the formations of canals and railroads, and other branches of national industry.

This review draws, therefore, upon experience of the oldest continuously existing scientific institution of its kind in the world.

William Smith had already published his geological map of England and Wales in 1815 ; mineral maps had appeared before the end of the 18th century in France, and De la Beche himself had coloured a series of the newly-published 1 mile to 1 inch topographic sheets for the Ministry of Agriculture. Some 
experience was, therefore, already available. Though evidently very heterogeneous in its lithological make up, the earth's crust was known to be capable of rational interpretation in terms of widely extensive rock formations in three-dimensional geometrical relationships with one another. Cuvier in France and Smith in England had already demonstrated that layers of sedimentary rocks often contained fossils of a highly characteristic order by which they could be recognised in widely separated outcrops. A division of geological time into eras, to which corresponded broad systems of rocks, was already being constructed in an international context.

The survey was recorded on the 1 inch (1:63 360) maps and published, hand coloured, at the same scale. The formations represented were described lithologically but classified as to geological system, the recognition of the age depending, as far as practicable, in the case of sedimentary rocks, upon the identification of characteristic fossils. The attitude of the layered formations (dip and strike) was recorded as well as the positions of faults shifting the run of the formation lines. For igneous rocks intrusive contacts were recorded where they could be shown to exist. Unconsolidated superficial formations, particularly river and marine alluvium and terraces, sand and gravel and boulder clay were shown by either ornament or washes.

In Britain the 6 inches to 1 mile topographic maps (1:10 560) began to appear in 1852 and this quickly became the main surveying scale, the advantage of its use being that in most areas, all individual rock outcrops could be recorded, and boundaries established with greater accuracy. The publication scale for areas other than those of special mining interest, remained the 1 inch. For each 1 inch sheet the mass of data collected proved to be too great to include on the map, and the practice of issuing descriptive memoirs, summarising this data, one for each sheet, was introduced.

It must be recognised at this stage that geological maps differ from topographic maps in an important respect-they necessarily embody an element, often a considerable element, of interpretation. Even in the best-exposed parts of the crust, for example, along the sides of ice-cut fjords and in arid mountain ranges, the solid rocks are never one hundred per cent visible. In most parts of the world, due to the cover of unconsolidated materials, soil and products of decay of vegetation, the percentage exposure is far less ; indeed in some places, the solid formations are scarcely revealed at all. Thus the geologist must use his skill to place the interpretation of the distribution of solid formations upon a basis of highest possible confidence. He was often aided, however, even in the earlier days of survey work, by subsurface information derived from wells, borings, mine workings and, occasionally, natural caverns. However it is well to recognise the limitations of such penetrations. The deepest 
mine, even today, in no more than $4 \mathrm{Km}$, and the deepest borehole $9 \mathrm{Km}$ deep. Most are far shallower, so that of a continental crust considered on geophysical evidence to average perhaps $30 \mathrm{Km}$ thick, we have direct access to a very shallow zone only.

Nevertheless, the surface and subsurface information available enables three-dimensional models of the upper part of the earth's crust to be constructed. The practice is to represent these on sections, often accompanying the maps or memoirs.

The process here described in outline, has been going on in the UK for 135 years. By this time we have a cover of mapping at the $1: 10560$ scale that includes more than 75 per cent of the country and 1 inch maps have been published for all Great Britain and Ireland, save for some small small parts of the Scottish Highlands and Islands. It is reasonable to ask, has this longcontinued work yielded results worthy of the effort entailed?

Considering first the scientific results of this and similar work in many other countries, it may be said briefly that they have provided the raw material and framework for the whole picture of invertebrate and vertebrate evolution, and they have revealed much of the complex history of the continental crust, including the establishment of the geosynclinal and orogenic tectonic belts that have affected it. They have revealed its response to loading with sediment and with thick ice on a continental scale. The details of volcanic activity and of igneous intrusion have emerged, at many different levels of erosion.

On the practical side, four areas of results of significance to society may be claimed. The nature, spatial positions and (to some extent) the origin of the concentrated deposits of fuels and useful minerals have emerged in perspective. The distribution and movement of groundwater without which life could not be maintained in many parts of the globe has been traced. The nature of foundation conditions for all kinds of engineering works, dams, buildings, and whole cities with all their complicated requirements is beginning to be understood in terms of Quaternary geology. Finally, geological survey has, or ought to have, provided an archive, preserving the details of expensive penetrations below the earth's surface for posterity.

The question may also be asked, why has not finality been reached before this time in the advanced countries ? The answer here is that improvements in techniques of geology and methods have been very considerable during the past century, and each advance has tended to render obsolete, in part at least, maps made without it. Of equal importance has been the fact that the 
accelerating pace of industrialisation and the demands of two world wars have given rise to large amounts of new subsurface information, all of which needs to be correlated and taken into account, calling for revision of existing maps, or production of new ones.

As examples of new techniques, the fast-developing field of geophysics and geochemistry must be cited. Sophisticated physical measurements have proved a remarkably effective means of obtaining subsurface information covering not only details of the crust but giving the position of its base (the Mohorovicic discontinuity) and information about the marvels beneath. Interpretation of the passage of seismic waves, natural and artificial, does all this and is a major aid to three-dimensional modelling. The variations in the magnetic field and in the force of gravity (the latter when suitably corrected for topography and for the geoid) bring out the positions of concealed sedimentary basins and intrusives. Electrical measurements, for example of resistivity, self-potential and induced potential are most valuable aids in the search respectively for water and metallic minerals.

In geochemistry, the development of physical methods of chemical analysis; notably atomic absorption, automated spectrometry, X-ray fluorescence and the electron microprobe have made it possible to deal effectively with vast numbers of samples. It is, for example, within the scope of a fairly modest laboratory to determine 1 million elements per year. Hence, technique is now available for the study of variation in major and trace elements on an areal and regional scale.

Geophysical and geochemical mapping thus now forms a normal part of geological survey.

The relevance of all this to modern society must finally be considered. Two features of modern society stand out immediately ; first the emergence of the independent developing nations, for the most part eager for industrialisation Secondly, the environmental pressures arising from the exponential increase in world population. In both areas I suggest that geological survey has a part to play that is vital to society.

The need for surveys in the developing countries, especially directed towards the development of water supplies and the discovery of useful mineral deposits is universally recognised, and receives the support of the governments of the countries concerned, of the United Nations Special Fund, as of much bilateral aid. Nevertheless, doubt may be expressed whether as much is being done as the situation demands. Progress can be far more rapid, at the reconnaissance stage, than was possible by traditional methods, by employing airborne photogeological methods, accompanied by ground traversing, and by using airborne 
geophysics. This does not yield detail at the degree of confidence already available in those countries mapped on scales such as the $1: 10,000$, but it is a valuable start from which target areas for more detailed attention may be selected. Perhaps there is no case for taking districts which are never likely to carry large conurbations or extensive industries up to the $1: 10,000$ scale of mapping ; but the gap between this and what generally exists at present is so large that effort beyond the present scope is certainly called for.

The environmental problem contains two highly important areas for geology. One is pollution and it is only necessary to note that a far wider application of the techniques of geochemistry is going to be called for if a proper appreciation of true background, against which chemical pollution can be assessed, is to be obtained.

The other area is that of non-renewable resources, dwindling in many cases at an excessively rapid rate. Search for new (and perhaps lower grade) areas where fuel deposits and concentrations of metals can be obtained will depend increasingly on geological surveying by all available techniques, especially after 'short cut' possibilities have been exhausted.

Perhaps for a time the sea will redress the balance of the land. Occupying 70 per cent of the earth's surface, it is the new target for geological survey. Here, geophysics, far more effective than on land, forms the spearhead of the attack; sea-bed sampling, shallow boring, deep seismic shooting and deep boring follow. This is the sequence for the continental shelf and slope, both with large hydrocarbon potential. The deep ocean, which demands different survey methods, may yet yield up its nickel and copper. But here, the dividend so far has been in pure science, where the breakthrough represented by continental drift, sea-floor spreading and plate-tectonics concepts has revolutionised thinking about our planet. It was the result of geophysical surveying at sea.

The pursuance of geological survey is, I feel sure, as much a matter for attention in Sri Lanka as it is elsewhere, both on shore and offishore. These reflections on our experience are offered with all good wishes for the success of the new Journal.

Hannover and London, June, 1973. 